\title{
Efficient myocyte gene delivery with complete cardiac surgical isolation in situ
}

\author{
Charles R. Bridges, MD, ScD, ${ }^{a}$ Kapil Gopal, MD, ${ }^{a}$ David E. Holt, BVSc, ${ }^{b}$ Charles Yarnall, BS, ${ }^{a}$ Steven Cole, VMD, ${ }^{\text {b }}$
} Rochelle B. Anderson, DVM, ${ }^{b}$ Xiaoqing Yin, MD, ${ }^{a}$ Anthony Nelson, BS, ${ }^{a}$ Benjamin W. Kozyak, BS, ${ }^{\text {a }}$ Zhonglin Wang, MD, James Lesniewski, MD, ${ }^{a}$ Leonard T. Su, MD, ${ }^{a}$ Danielle M. Thesier, BS, ${ }^{a}$ Hari Sundar, BE, ${ }^{a}$ and Hansell H. Stedman, MD

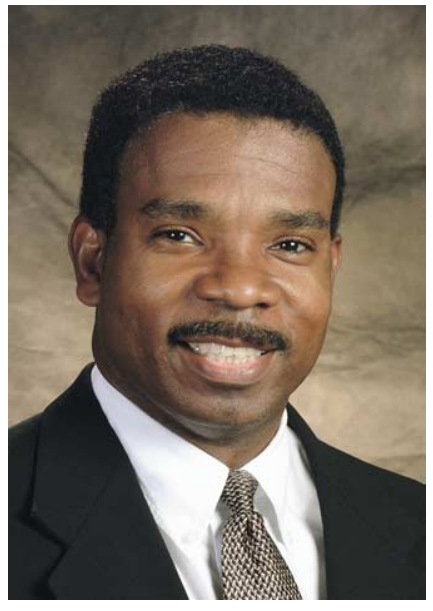

Dr Bridges

\section{eonly Additional material is available online.}

From the Departments of Surgery of the University of Pennsylvania Health System, ${ }^{\text {a }}$ and the Veterinary Hospital of the University of Pennsylvania, ${ }^{\text {b }}$ Philadelphia, Pa.

This work was supported by the National Institutes of Health/National Institute of Biomedical Imaging and Bioengineering grant 1-R21-EB003223-01. K.G. and L.T.S. were supported by the National Institutes of Health gene therapy training grant T32DK07748-07.

Received for publication Jan 3, 2005; revisions received May 2, 2005; accepted for publication July 5, 2005.

Address for reprints: Charles R. Bridges, MD, $\mathrm{ScD}$, Department of Surgery, the University of Pennsylvania Health System, 4 Silverstein, Hospital of the University of Pennsylvania, Philadelphia, Pa., 19104 (E-mail: cbridges@ pahosp.com).

J Thorac Cardiovasc Surg 2005;130:1364-70

0022-5223/\$30.00

Copyright () 2005 by The American Association for Thoracic Surgery

doi:10.1016/j.jtcvs.2005.07.035
Background: Previously, we used cardiopulmonary bypass with incomplete cardiac isolation and antegrade administration of vector for global cardiac gene delivery. Here we present a translatable cardiac surgical procedure that allows for complete surgical isolation of the heart in situ with retrograde (through the coronary venous circulation) administration of both vector and endothelial permeabilizing agents to increase myocyte transduction efficiency.

Methods: In 6 adult dogs the heart was completely isolated with tourniquets placed around both vena cavae and cannulas and all pulmonary veins. On cardiopulmonary bypass, the aorta and pulmonary artery were crossclamped, and the heart was isolated. Crystalloid cardioplegia at $4^{\circ} \mathrm{C}$ containing $10^{13}$ particles of adenovirus encoding LacZ and $15 \mu \mathrm{g}$ of vascular endothelial growth factor was infused retrograde into the coronary sinus and recirculated for a total of 30 minutes. The dogs were then weaned from cardiopulmonary bypass and allowed to recover. With a catheter, 3 control dogs underwent retrograde infusion of the same cocktail without cardiac isolation or cardiopulmonary bypass.

Results: $\beta$-Galactosidase activities in the cardiopulmonary bypass group were several orders of magnitude higher in both the right and left ventricles when compared with those in the control group $(P<.05)$. X-gal staining from the cardiopulmonary bypass group showed unequivocal evidence of myocyte gene expression globally in a significant proportion of cardiac myocytes. No myocyte gene expression was observed in the control group.

Conclusion: A novel cardiac surgical technique has been developed. This approach with cardiac isolation and retrograde delivery of vector through the coronary sinus results in efficient myocyte transduction in an adult large animal in vivo.

$\mathrm{M}$ ore than half of the cardiovascular deaths in the United States are due to heart failure, which still carries an unacceptably high mortality. ${ }^{1,2}$ There has not been a single clinical trial of gene therapy for the treatment of heart failure, although some are now being proposed. ${ }^{3}$ In contrast, there have been several trials designed to treat patients with coronary artery disease with both catheter-based intracoronary infusion or direct intramyocardial injection for gene delivery. ${ }^{3-9}$

A variety of studies using both adult murine and rodent animal models and transgenic models of heart failure have identified promising transgenes for the treatment of heart failure. ${ }^{10-17}$ These include the $\beta$-adrenoreceptor kinase c-terminus $\left(\beta\right.$ ARKct) ${ }^{10,11}$ the sarcoplasmic reticulum $\mathrm{Ca}^{2+}$ ATPase 2a (SERCA2a), ${ }^{12-15}$ and the pseudophosphorylated mutant of phospholamban (S16EPLN). ${ }^{16,17}$ In spite of this progress, there has never been a convincing demonstration of transduction of the majority of cardiac myocytes in situ in a large adult mammal. Thus we believe that 


\section{Abbreviations and Acronyms \\ $\mathrm{AAV}=$ adeno-associated virus \\ $\mathrm{CPB}=$ cardiopulmonary bypass \\ VEGF $=$ vascular endothelial growth factor}

the development of translational methods for efficient transgene delivery in a large adult animal model is the most important remaining obstacle in the development of effective gene therapy for heart failure.

The endothelial barrier is the proximate rate limiter for the achievement of widespread transvascular vector-mediated gene delivery to skeletal myocytes in situ. ${ }^{18}$ We have previously used cardiopulmonary bypass (CPB) as a means of delivering adenovirus encoding LacZ to canine animals. ${ }^{19}$ We achieved incomplete (1-way) isolation of the heart because the pulmonary veins were not controlled ${ }^{19}$ and no endothelial permeabilizing agents were administered. On the basis of our previous observations, ${ }^{18}$ we were not surprised when this approach resulted in global delivery but transduction of only a small minority of cardiac myocytes in the heart. ${ }^{19}$

Because the capillaries lie on the venous side of the arteriolar resistor, retrograde (eg, venous to arterial) vector infusion should result in a higher capillary to interstitial pressure gradient, favoring filtration of the macromolecular assembly (vector). We and others ${ }^{20}$ hypothesized that a retrograde (venous to arterial) infusion approach would result in enhanced transduction efficiency. Here we present a new cardiac surgical procedure that allows for complete (2-way) isolation of the heart in situ. We used this unique approach for the first time to deliver Ad.CMV.LacZ to the heart of an adult canine mammal in situ. In contrast to previous applications of CPB for vector-mediated gene delivery, ${ }^{19,21,22}$ this technique allows us to coinfuse an endothelial permeabilizing agent (vascular endothelial growth factor [VEGF]) while avoiding potentially untoward systemic side effects in an attempt to limit gene expression to the heart. The therapeutic margin of safety is thus enhanced by minimizing the risk of collateral gene expression in the germ line or cornea. We also compare, using quantitative and histochemical methods, the relative transduction efficiency of our novel delivery technique to a control group in which an equal titer of vector and equal dose of VEGF are administered retrograde directly through a catheter in the coronary sinus. The control group simulates what could be achieved with a percutaneous catheter-based transvascular vector delivery technique in a large adult mammal.

\section{Methods}

Both the experimental group, $(n=6, \mathrm{CPB}$ group) and the control group, ( $\mathrm{n}=3$, catheter group) consist of normal adult male dogs, each weighing approximately $20 \mathrm{~kg}$. Animals in the CPB group undergo gene delivery by a novel cardiac isolation procedure with retrograde infusion and recirculation of vector with CPB described below. Animals in the catheter group undergo gene delivery with a catheter introduced into the coronary sinus without CPB and without isolation of the heart. All animals are cared for in a humane fashion and in compliance with the "Guide for the Care and Use of Laboratory Animals" (www.nap.edu/catalog/ $5140 . \mathrm{html}$ ). One hour before surgical intervention, each animal is premedicated with acepromazine $(0.1 \mathrm{mg} / \mathrm{kg})$ and glycopyrrolate $(0.001 \mathrm{mg} / \mathrm{kg}$; INN: glycopyrronium bromide). General anesthesia is induced with ketamine $(10 \mathrm{mg} / \mathrm{kg})$ and diazepam $(0.5 \mathrm{mg} / \mathrm{kg})$ intravenously and maintained with inhaled oxygen and isoflurane $(1 \%-2 \%)$. Cefazolin $(25 \mathrm{mg} / \mathrm{kg}$ intravenously) is administered prophylactically.

\section{CPB Group}

The left femoral artery is cannulated. A median sternotomy incision is made, and the sternum is divided. Excess thymus tissue is excised (if necessary). Aminocaproic acid (Amicar), $5 \mathrm{~g}$, is administered intravenously. All cannulas and stopcocks are preflushed with albumin to avoid inactivation of adenovirus. ${ }^{23}$ Pursestring sutures are placed around the right atrial appendage, on the right atrium adjacent to the atrioventricular groove, and on the right atrium near its junction with the inferior vena cava. A no. 1 silk heavy suture is doubly placed around the superior vena cava and connected to a tourniquet. With the use of pericardial pledgets and 4-0 Prolene sutures, a horizontal mattress pledgeted-supported suture is placed on the ascending aorta approximately $1 \mathrm{~cm}$ distal to the aortic root. The aorta and pulmonary artery are ensnared with umbilical tapes. The pulmonary artery is ensnared by exclusion. Heparin is administered $(130 \mathrm{U} / \mathrm{kg})$. The right carotid artery is cannulated with a $12 \mathrm{~F}$ cannula. By using the previously placed purse-string sutures, (1) a cardioplegia cannula (containing a vent limb) is placed in the ascending aorta, (2) the superior vena cava is cannulated with a $26 \mathrm{~F}$ right angle cannula, (3) a retrograde catheter is placed into the coronary sinus, and (4) the inferior vena cava is cannulated with a $26 \mathrm{~F}$ right angle cannula. The 2 venous cannulas are connected to a $\mathrm{Y}$ connector and connected to the venous limb of the pump circuit. CPB is initiated. All of the pulmonary veins are ensnared, individually or in groups, by umbilical tapes and tourniquets. The azygos vein is ligated. The inferior vena cava is snared with a double loop of 0 silk sutures. A purse-string suture is placed in the apex of the left ventricle. Volume is left in the heart. A stab is made in the middle of the purse string, and a cannula is placed into the left ventricular cavity and clamped. A pledget-supported purse-string suture is placed in the right ventricular outflow tract. A cannula is then placed into the right ventricle and clamped, and the purse string is snared.

The cardiac circuit is constructed. Systemic cooling to $30^{\circ} \mathrm{C}$ is initiated. Once the heart fibrillates, the aorta is crossclamped, and $50 \mathrm{mg}$ of diphenhydramine (Benadryl), $100 \mathrm{mg}$ of methylprednisolone, and $300 \mathrm{mg}$ of cimetidine are administered systemically and simultaneously. Plegisol (Abbott Laboratories, Chicago, Ill; $\mathrm{pH}$ adjusted with sodium bicarbonate to $\mathrm{pH}=7.4$ ), $300 \mathrm{~mL}$, at $4^{\circ} \mathrm{C}$ is administered to arrest the heart. The virus solution is constituted when bypass is initiated and consists of $10^{13}$ particles of Ad.CMV. LacZ along with $5 \mu \mathrm{g}$ of human VEGF 121 (Pepro-tech, Rocky 


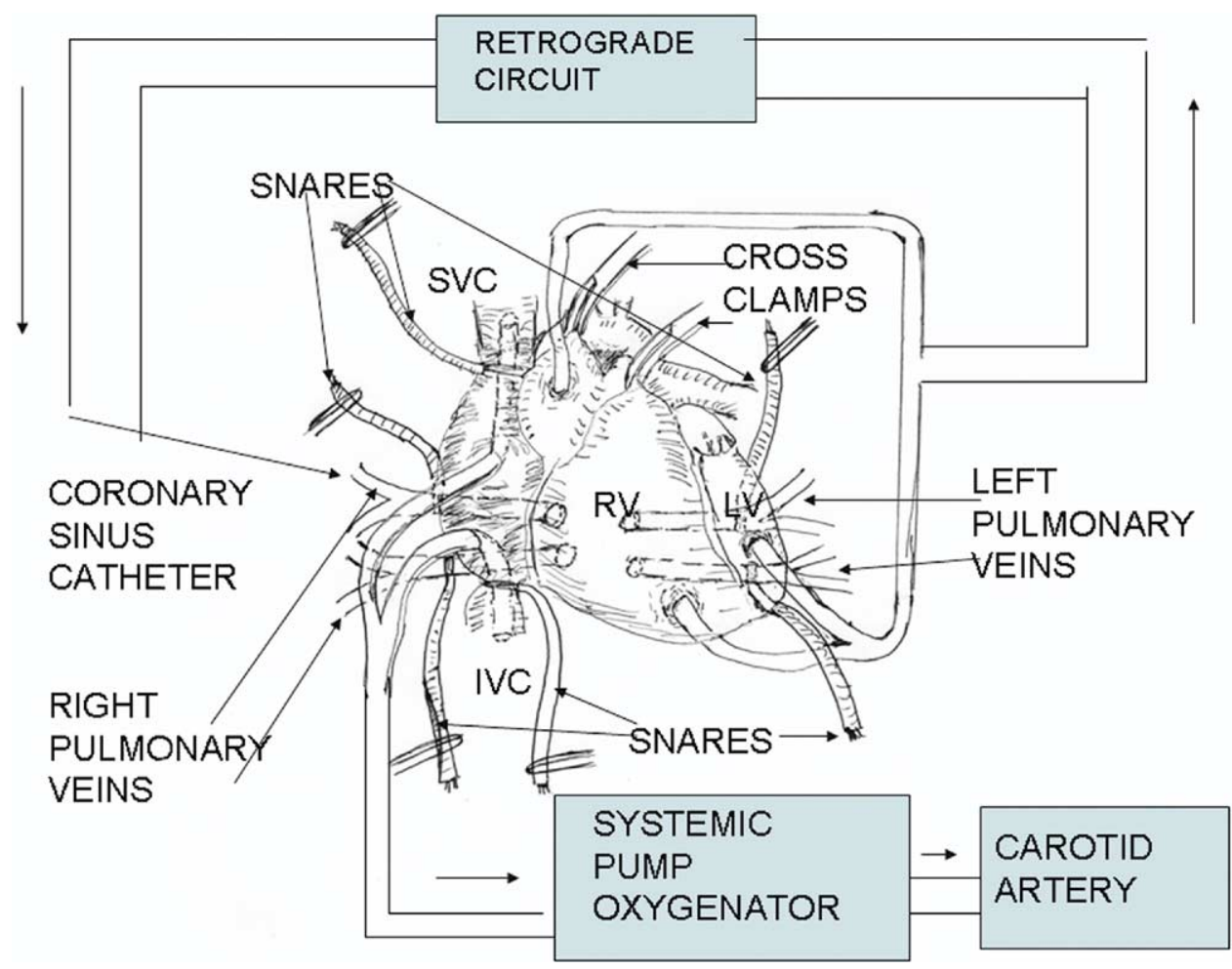

Figure 1. Schematic diagram of the cardiac isolation circuit. SVC, Superior vena cava; $R V$, right ventricle; $L V$, left ventricle; IVC, inferior vena cava.

Hill, NJ) and $10 \mu \mathrm{g}$ of VEGF 165 (Sigma-Aldrich, St Louis, Mo) in a total of $5 \mathrm{~mL}$ of phosphate-buffered saline. The coronary circuit is isolated, and the heart is emptied of excess volume and air. Flow into the now-isolated cardiac circuit is resumed and progressively increased until the coronary sinus pressure equals 60 to $80 \mathrm{~mm} \mathrm{Hg}$ (typically flow is approximately $100-150 \mathrm{~mL} / \mathrm{min}$ ). Then one half of the virus solution (approximately $2.5 \mathrm{~mL}$ ) is injected slowly into a $50-\mathrm{mL}$ volume (approximately $2.5 \mathrm{~mL} / \mathrm{kg}$ over 30 seconds at a circuit flow rate of $100 \mathrm{~mL} / \mathrm{min}$ ). Circulation is stopped, and the solution is allowed to dwell for 10 minutes. Flow is restored over 1 minute to 100 to $120 \mathrm{~mL} / \mathrm{min}$, with coronary sinus pressure equal to 60 to $80 \mathrm{~mm} \mathrm{Hg}$, and the remaining $2.5 \mathrm{~mL}$ of virus solution is infused, again over 30 seconds, and recirculated for another 20 minutes. During this interval, the flow is slowly increased to a maximum of $150 \mathrm{~mL} / \mathrm{min}$ as needed to maintain a coronary sinus pressure of 60 to $80 \mathrm{~mm} \mathrm{Hg}$. The coronary sinus catheter is then removed, and the suture is tied. The coronary circuit is then flushed antegrade with approximately 500 $\mathrm{mL}$ of a colloid solution with $100 \mathrm{mg}$ of methylprednisolone, 50 $\mathrm{mg}$ of diphenhydramine, and $300 \mathrm{mg}$ of cimetidine added. The aortic crossclamp is removed, and flow is restored. Rewarming is initiated. The inferior vena cava, superior vena cava, and pulmonary vein snares are removed. The right ventricular and left ventricular cannulas are converted to systemic vents. The aortic root cannula is removed. Epinephrine is administered at 1 to $2 \mu \mathrm{g} / \mathrm{min}$. Lidocaine (50 mg bolus) is administered, and an infusion is begun at $1 \mathrm{mg} / \mathrm{min}$. An additional dose of $100 \mathrm{mg}$ of methylprednisolone, $50 \mathrm{mg}$ of diphenhydramine, and $300 \mathrm{mg}$ of cimetidine is administered. Aminocaproic acid, $5 \mathrm{mg}$, is administered intravenously. After approximately 5 minutes of systemic venting, the crossclamp on the pulmonary artery is removed. The aortic cannula is removed. The right ventricular cannula is removed. Once the heart is contracting well, the left ventricular cannula is removed. Bypass is discontinued after 30 minutes of reperfusion. Once hemodynamic stability is achieved and the heparin is reversed, the chest is closed. A schematic drawing of the cardiac isolation procedure appears in Figure 1.

\section{Catheter Group}

A median sternotomy incision is made, and the sternum is divided. A purse string is placed on the right atrium adjacent to the atrioventricular groove. The retrograde catheter is placed into the coronary sinus. As in the bypass group, the virus solution consists of $10^{13}$ particles of Ad.CMV.LacZ along with $5 \mu \mathrm{g}$ of human VEGF 121 and $10 \mu \mathrm{g}$ of human VEGF 165 in $5 \mathrm{~mL}$ of phosphatebuffered saline. One half of the solution $(2.5 \mathrm{~mL})$ is injected over 30 seconds, with care to clear the catheter dead space $(2 \mathrm{~mL})$ before starting the 30 -second infusion interval. The solution is allowed to dwell for 10 minutes. The remaining $2.5 \mathrm{~mL}$ of virus solution is infused over 30 seconds (as above) and allowed to dwell for 20 minutes. The retrograde catheter is then removed. The chest is closed. 


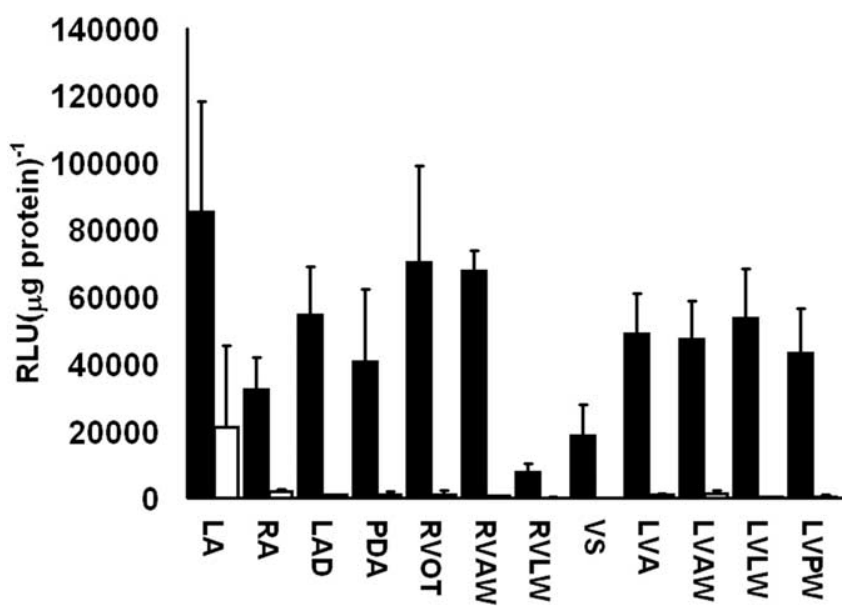

Figure 2. $\beta$-Galactosidase activities in the hearts in the cardiopulmonary bypass (CPB) group (CPB with complete in situ cardiac isolation, filled bars) and the catheter group (control; catheter infusion without CPB and without cardiac isolation, open bars). $R L U$, Relative light units; $L A$, left atrium; $R A$, right atrium; $L A D$, left anterior descending coronary artery; $P D A$, posterior descending coronary artery; RVOT, right ventricular outflow tract; $R V A W$, right ventricular anterior wall; $R V L W$, right ventricular lateral wall; VS, ventricular septum; $L V A$, left ventricular apex; $L V A W$, left ventricular anterior wall; $L V L W$, left ventricular lateral wall; LVPW, Left ventricular posterior wall.

\begin{abstract}
Assessment of Gene Expression
Within approximately 4 hours after completion of the procedure, the animals were weaned from mechanical ventilation and inotropic support, and all chest tubes were removed. For animals in the $\mathrm{CBP}$ and catheter groups, tissues were procured at necropsy on day 6 or 7 after death with an intravenous overdose of sodium pentobarbital. Cryostat sections of the heart, liver, testis, diaphragm, and other organs were incubated overnight at room temperature in $\mathrm{X}$-gal solution. $\beta$-Galactosidase enzyme activity was quantified with a chemiluminescent reporter assay system (Galacto-Light Plus; Tropix, Inc, Bedford, Mass).
\end{abstract}

\section{Statistical Methods}

For comparisons of $\beta$-galactosidase activities, a 2 -sample Student $t$ test was performed between the 2 groups (catheter vs CPB).

\section{Results}

All animals in the catheter group and 5 of 6 animals in the CPB group survived to euthanasia. $\beta$-Galactosidase activities in the CPB group were several orders of magnitude higher in both the right and left ventricles when compared with those of the control group $(P<.05$, Figure 2$)$. In contrast, $\beta$-galactosidase activities in the CPB group were significantly lower in the liver but significantly higher in the diaphragm and rectus abdominis than in the catheter group $(P<.05$, Table E1). X-gal staining from the CPB group showed unequivocal evidence of myocyte gene expression globally in a significant proportion of cardiac myocytes. No myocyte gene expression was observed in the hearts of the catheter group (Figure 3). Whole mount sections stained with X-gal
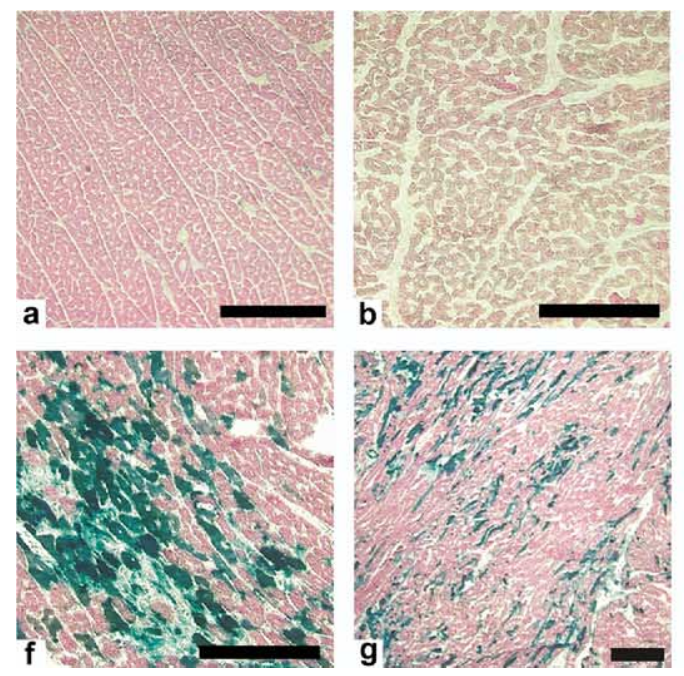
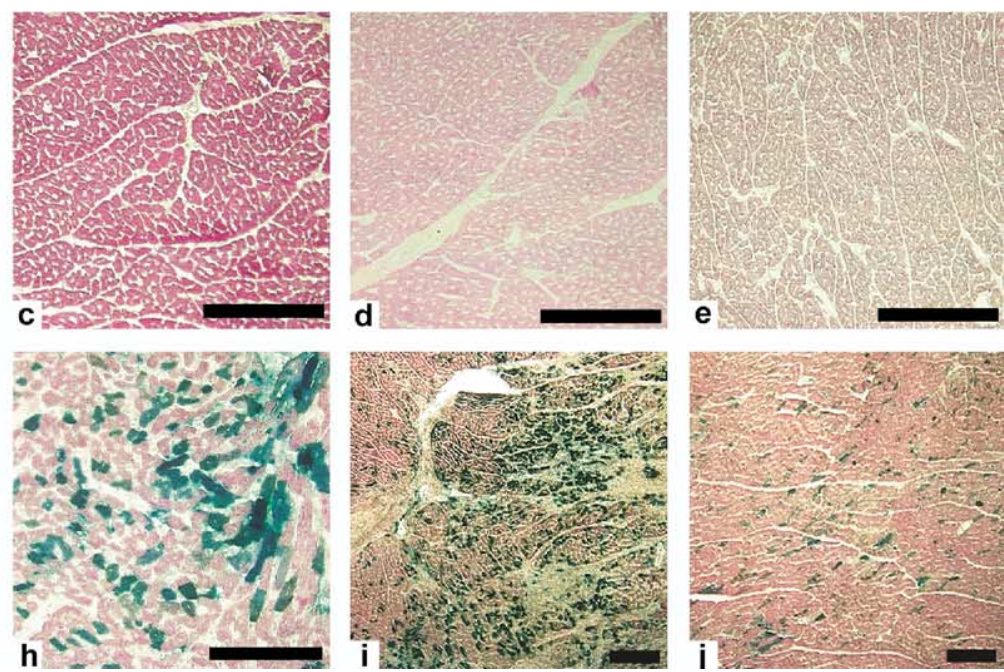

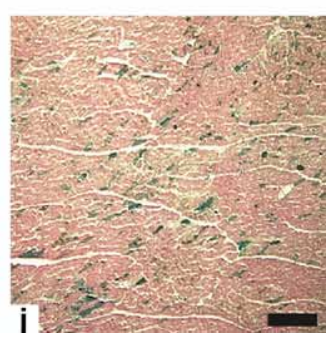

Figure 3. X-gal staining of gene transfer into left and right ventricular cardiomyocytes in the catheter group (a-e) and the CPB group ( $f-j)$. Depicted are photomicrographs of the left ventricular apex (a and $f ; 10 \times$; bar $=0.250 \mathrm{~mm}$ ), left ventricular lateral wall (b and g; $4 \times$; bar $=0.250 \mathrm{~mm}$ ), left ventricular anterior wall (c and $h ; 10 \times$; bar $=0.250$ $\mathrm{mm}$ ), right ventricular anterior free wall (d and $\mathrm{i} ; 4 \times$; bar $=0.250 \mathrm{~mm}$ ), and right ventricular posterior wall (e and j; $4 \times$ ) 1 week after infusion of $10^{13}$ particles of Ad.CMV.LacZ along with $15 \mu \mathrm{g}$ of vascular endothelial growth factor and staining with X-gal 1 week postoperatively. 

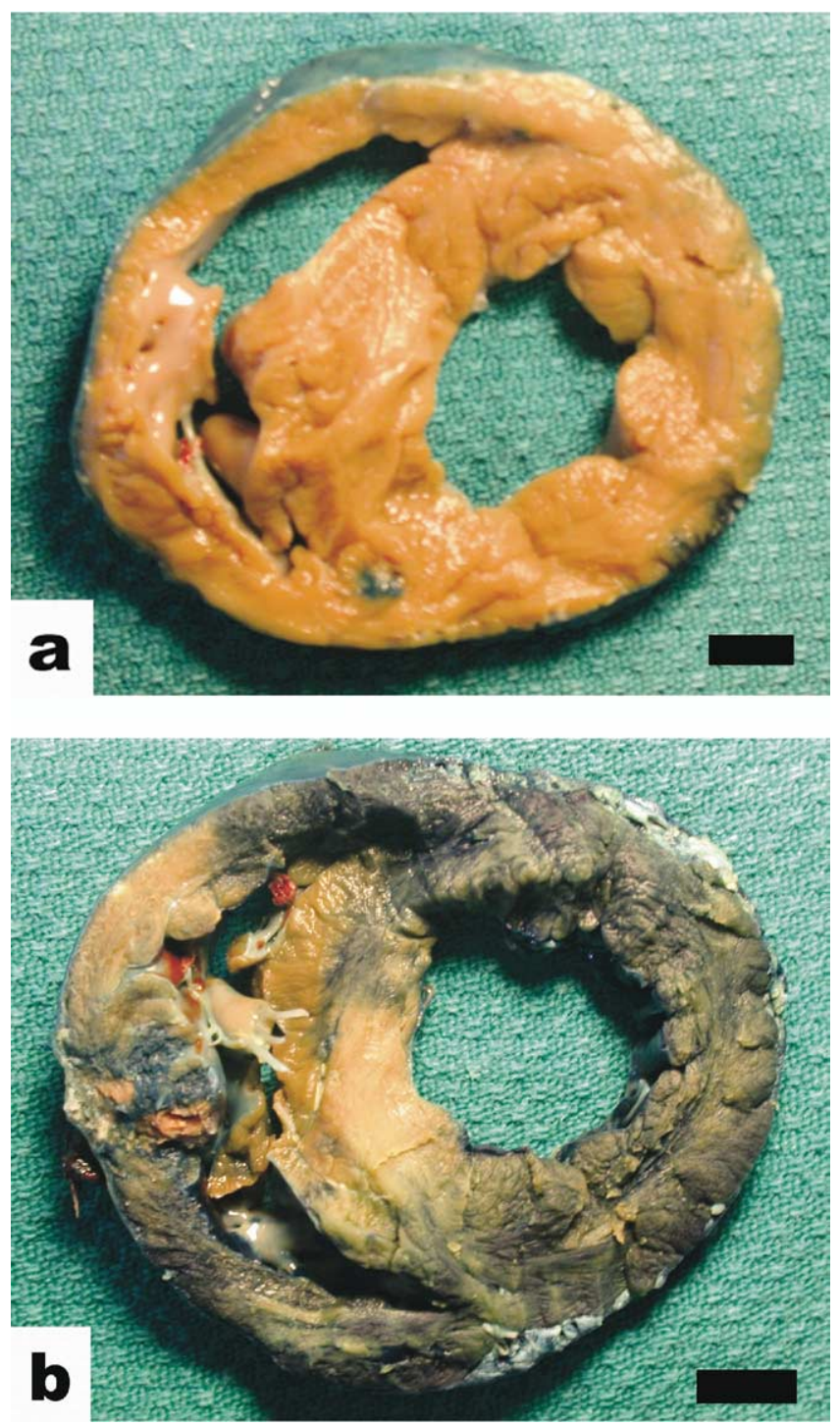

Figure 4. X-gal staining of whole mounts of short-axis crosssections of hearts derived from the catheter group (a) and the CPB group (b). Both panels a and $b$ represent sections obtained at 1 week after vector delivery.

demonstrate transmural LacZ expression that is most pronounced in the left ventricle in the CPB group. There was no evidence of gene expression in the catheter group (Figure 4).

\section{Discussion}

Gene therapy for heart failure is an exciting yet immature field of investigation. For the recessively inherited cardiomyopathies, such as those associated with the sarcoglycan deficiencies, ${ }^{24} \mathrm{X}$-linked cardiomyopathy, ${ }^{25}$ or the cardiomyopathy associated with Becker's muscular dystrophy, ${ }^{26}$ optimal therapy will almost certainly require expression of the missing or dysfunctional gene to correct the heart failure phenotype. For gene therapy to be optimally effective, expression of an appropriate transgene will be required in a substantial percentage of cardiomyocytes. Unlike gene therapy for coronary artery disease, in which an important goal has been induction of collateral blood vessel formation where short-term gene expression might be sufficient or even desirable, optimal gene therapy for heart failure will likely require expression of the transgene in a significant percentage of cardiac myocytes in the long term.

In this regard, Gregorevic and associates ${ }^{27}$ have demonstrated that adeno-associated virus (AAV) pseudotype 6 encoding LacZ transduced the majority of striated myocytes, including the diaphragm, heart, and limb muscles, after a single intravenous injection in adult mice and adult hamsters. However, by using this approach, doses of vector required in human subjects (approximately $10^{16}-10^{17}$ vector genomes) would likely be prohibitive. In contrast, our gene delivery method allows for a higher concentration (approximately $100 \times$ ) of vector to be delivered to the target organ (heart) than would be achieved with a systemic intravenous injection. As a result, the finding of AAV pseudotypes that appear to have the ability to bypass the endothelial barrier to a greater extent than previously appreciated is likely to increase the therapeutic efficacy when used in conjunction with the complete 2-way cardiac isolation delivery technique presented.

The basement membrane is an important component of the endothelial barrier, presenting both electrostatic and steric restriction to the transcapillary passage of macromolecular complexes. ${ }^{28} \mathrm{We}$ were fascinated by the observation that there is a marked increase in the thickness of the microvascular basal lamina as a function of postural hydrostatic pressure. ${ }^{29}$ These observations might provide a hypothesis to explain why vector-mediated transvascular gene delivery to striated muscle has previously been far more successful in mice and rodents than in large animals.

In this study we have shown, for the first time, a convincing and unequivocal demonstration of transgene expression in a significant percentage of cardiac myocytes in the heart of a large adult mammal in situ using a transvascular route of delivery with an adenoviral vector. Furthermore, the study demonstrates that equivalent results could not be achieved with a simple retrograde catheter infusion technique. Complete surgical isolation of the heart in situ, using $\mathrm{CPB}$ with retrograde coronary sinus infusion and recirculation of vector through the heart, results in an increase of several orders of magnitude in $\beta$-galactosidase activities in the heart, significantly lower $\beta$-galactosidase activities in the liver, and no histochemical evidence of transgene expression in the liver. In each of the key comparisons, the differences between the $\mathrm{CPB}$ group and the catheter group 
are highly statistically significant. The differences in the histochemical findings are equally striking. We did notice higher $\beta$-galactosidase activities in the diaphragm, rectus abdominis, and lung in the CPB group than in the catheter group. This observation most likely represents the higher concentrations of vector achieved in the heart in the CPB group and the effects of small collateral arteries between the heart and the lungs, diaphragm, and chest wall.

One limitation of this approach is that gene expression is most evident in the left ventricle and less convincingly demonstrated in the right ventricle and ventricular septum. Our hypothesis is that this distribution of gene expression is due to the fact that the right ventricular and septal venous effluent drains into the proximal portion of the coronary sinus (ie, proximal to the position of the coronary sinus catheter balloon). In direct analogy to our findings, it is well recognized that retrograde cardioplegia administration provides inadequate delivery to the right ventricle. ${ }^{30}$ We are addressing this limitation by developing new retrograde catheters (Bridges and associates, inventors, US patent pending) designed to allow for global retrograde delivery. Another limitation of this technique is that CPB is required. Furthermore, we use an infusion pressure of up to $80 \mathrm{~mm}$ $\mathrm{Hg}$, nearly twice the $40 \mathrm{~mm} \mathrm{Hg}$ limit typically used clinically. However, it is not uncommon to use simultaneous (antegrade-retrograde) cardioplegia delivery in which substantially higher retrograde pressures might be achieved without apparent myocardial injury. Furthermore, we did not find clinical or histologic evidence of significant myocardial toxicity or inflammatory changes using this technique. Adenovirus, although useful for these short-term experiments, would need to be replaced with a vector, such as AAV, to achieve the long-term gene expression necessary for heart failure gene therapy.

We believe that appropriate modifications of the procedures used here, using therapeutic transgenes and an AAV delivery vector, might theoretically be added as an adjunct to valve repair or replacement surgery, coronary artery bypass graft surgery, or ventricular assist device implantation procedures in selected patients with heart failure. In younger patients with known X-linked or autosomal recessive cardiomyopathy, this approach might be used as primary therapy, ideally before cardiac function had deteriorated significantly.

In summary, CPB with complete surgical isolation of the heart is one potential approach to solving the problem of efficient global transvascular vector-mediated transgene delivery to striated muscle in the heart, currently the ratelimiting problem in the development of effective strategies for gene therapy for heart failure. Furthermore, this approach might also have merit in the delivery of angiogenic transgenes to the myocardium to treat coronary ischemia, particularly in situations in which global delivery is desir- able. In these situations gene delivery to ischemic areas could be accomplished efficiently by using the retrograde approach presented. In appropriate patients these methods might one day allow molecular cardiac surgery to provide a viable alternative to the artificial heart or cardiac transplantation.

\section{References}

1. American Heart Association. 2002 Heart and stroke statistical update. Dallas [TX]: American Heart Association; 2001.

2. Levy D, Kenchaiah S, Larson GM, Benjamin JE, Kupka JM, Ho KL, et al. Long-term trends in the incidence of and survival with heart failure. N Engl J Med. 2002;347:1397-402.

3. Isner JM. Myocardial gene therapy. Nature. 2002;415:234-9.

4. Grines CL, Watkins MW, Helmer G, Penny W, Brinker J, Marmur JD, et al. Angiogenic gene therapy (AGENT) trial in patients with stable angina pectoris. Circulation. 2002;105:1291-7.

5. Vale PR, Lorsordo DL, Milliken CE, McDonald MC, Gravelin LM, Curry CM, et al. Randomized, single-blind, placebo-controlled pilot study of catheter-based myocardial gene transfer for therapeutic angiogenesis using left ventricular electromechanical mapping patients with chronic myocardial ischemia. Circulation. 2001;103:2138-43.

6. Rosengart TK, Lee LY, Patel SR, Sanborn TA, Parikh M, Bergman $\mathrm{GW}$, et al. Angiogenesis gene therapy: phase I assessment of direct intramyocardial administration of an adenovirus vector expressing VEGF121 Cdna to individuals with clinically significant severe coronary artery disease. Circulation. 1999;100:468-74.

7. Rosengart TK, Lee LY, Patel SR, Kligfield PD, Okin PM, Hackett NR, et al. Six month assessment of a phase I trial of angiogenic gene therapy for the treatment of coronary artery disease using direct intramyocardial administration of an adenovirus vector expressing the VEGF 121 cDNA. Ann Surg. 1999;230:466-70.

8. Symes JF, Losordo DW, Vale PR, Lathi KG, Esakof DD, Mayskiy M, et al. Gene therapy with vascular endothelial growth factor for inoperable coronary artery disease. Ann Thorac Surg. 1999;68:830-7.

9. Vincent KA, Shyu KG, Luo Y, Magner M, Tio RA, Jiang C, et al. Angiogenesis is induced in a rabbit model of hindlimb ischemia by naked DNA encoding an hif- $1 \alpha / \mathrm{VP} 16$ hybrid transcription factor. Circulation. 2000;102:2255-61.

10. Emani SM, Shah AS, White DC, Glower DD, Koch WJ. Right ventricular gene therapy with a beta-adrenergic receptor kinase inhibitor improves survival after pulmonary artery banding. Ann Thorac Surg. 2001;72:1657-61.

11. Manning BS, Shotwell K, Mao L, Rockman HA, Koch WJ. Physiological induction of a beta-adrenergic receptor kinase inhibitor transgene preserves ss-adrenergic responsiveness in pressure-overload cardiac hypertrophy. Circulation. 2000;102:2751-7.

12. Del Monte F, Williams E, Lebeche D, Schmidt U, Rosenzweig A, Gwathmey JK, et al. Improvement in survival and cardiac metabolism after gene transfer of sarcoplasmic reticulum $\mathrm{Ca}(2+)$-ATPase in a rat model of heart failure. Circulation. 2001;104:1424-9.

13. Schmidt U, Del Monte F, Miyamoto MI, Matsui T, Gwathmey JK, Rosenzweig A, et al. Restoration of diastolic function in senescent rat hearts through adenoviral gene transfer of sarcoplasmic reticulum $\mathrm{Ca}$ (2+)-ATPase. Circulation. 2000;101:790-6.

14. Miyamoto MI, Del Monte F, Schmidt U, DiSalvo TS, Kang ZB, Matsui $\mathrm{T}$, et al. Adenoviral gene transfer of SERCA2a improves left-ventricular function in aortic-banded rats in transition to heart failure. Proc Natl Acad Sci U S A. 2000;97:793-8.

15. Hajjar RJ, Schmidt U, Matsui T, Guerrero JL, Lee KH, Gwathmey JK, et al. Modulation of ventricular function through gene transfer in vivo. Proc Natl Acad Sci U S A. 1998;95:5251-6.

16. Hoshijima M, Ikeda Y, Iwanaga Y, Minamisawa S, Date MO, Gu Y, et al. Chronic suppression of heart-failure progression by a pseudophosphorylated mutant of phospholamban via in vivo cardiac rAAV gene delivery. Nat Med. 2002;8:864-71.

17. Ikeda Y, Gu Y, Iwanaga Y, Hoshijima M, Oh SS, Giordano FJ, et al. Restoration of deficient membrane proteins in the cardiomyopathic 
hamster by in vivo cardiac gene transfer. Circulation. 2002;1054: 502-8.

18. Greelish JP, Su LT, Lankford EB, Burkman JM, Chen H, Konig SK, et al. Stable restoration of the sarcoglycan complex in dystrophic muscle perfused with histamine and a recombinant adeno-associated viral vector. Nat Med. 1999;5:439-43.

19. Bridges CR, Burkman JM, Malekan R, Konig S, Chen H, Yarnall CB, et al. Global cardiac-specific transgene expression using cardiopulmonary bypass with cardiac isolation. Ann Thorac Surg. 2002;73:1939-46.

20. Boekstegers P, von Degenfeld G, Giehrl W, Heinrich D, Hullin R, Kupatt C, et al. Myocardial gene transfer by selective pressure-regulated retroinfusion of coronary veins. Gene Ther. 2000;7:232-40.

21. Davidson MJ, Jones JM, Emani SM, Wilson KH, Jaggers J, Koch WJ, et al. Cardiac gene delivery with cardiopulmonary bypass. Circulation. 2001;104:131-3.

22. Jones JM, Wilson KH, Koch WJ, Milano CA. Adenoviral gene transfer to the heart during cardiopulmonary bypass: effect of myocardial protection technique on transgene expression. Eur J Cardiothorac Surg. 2002;21:847-52.

23. Marshall DJ, Palasis M, Lepore JJ, Leiden JM. Biocompatibility of cardiovascular gene delivery catheters with adenovirus vectors: an important determinant of the efficiency of cardiovascular gene transfer. Mol Ther. 2000;1:423-9.
24. Duggan DJ, Gorospe JR, Fanin M, Hoffman EP, Angelini C. Mutations in the sarcoglycan genes in patients with myopathy. $N$ Engl J Med. 1997;336:618-24.

25. Muntoni F, Cau M, Ganau A, Congiu R, Arvedi G, Mateddu A, et al. Brief report. Deletion of the dystrophin muscle-promoter region associated with X-linked dilated cardiomyopathy. N Engl J Med. 1993; 329:921-2.

26. Yoshida K, Ikeda S, Nakamura A, Kagoshima M, Takeda S, Shoji S, et al. Molecular analysis of the Duchenne muscular dystrophy gene in patients with Becker muscular dystrophy presenting with dilated cardiomyopathy. Muscle Nerve.1993;16:1161-6.

27. Gregorevic P, Blankinship JM, Allen JM, Meuse L, Miller DG, Russell DW, et al. Systemic gene transfer to striated muscles using adeno-associated viral vectors. Nature. 2004;10:828-34.

28. Deen WM, Bridges CR, Brenner BM, Myers BD. Heteroporous model of glomerular size selectivity: application to normal and nephrotic humans. Am J Physiol. 1985;249:F374-89.

29. Williamson JR, Vogler NJ, Kilo C. Regional variations in the width of the basement membrane of muscle capillaries in man and giraffe. Am J Pathol. 1971;63:359-70.

30. Balsam GM, Huynh TT, Benny C, Cusson D, Morin JF. Assessment of right ventricular function postretrograde cardioplegia by transesophageal echocardiography. J Card Surg. 1998;13:32-6. 
TABLE E1. Noncardiac tissue $\beta$-galactosidase activities

\begin{tabular}{|c|c|c|c|}
\hline Tissue & $\begin{array}{l}\text { CPB group, } \mathrm{RLU} / \mu \mathrm{g} \text { protein } \\
\text { (with cardiac isolation) }\end{array}$ & $\begin{array}{l}\text { Catheter group } \mathrm{RLU} / \mu \mathrm{g} \text { protein } \\
\text { (without cardiac isolation) }\end{array}$ & $P$ value \\
\hline Left lung & $3794 \pm 2755$ & $48 \pm 4$ & .203 \\
\hline Right lung & $10,225 \pm 9192$ & $32 \pm 10$ & .283 \\
\hline Diaphragm* & $2776 \pm 933$ & $157 \pm 76$ & .035 \\
\hline Rectus abdominis* & $616 \pm 180$ & $50 \pm 29$ & .024 \\
\hline Right liver* & $4 \pm 2$ & $30 \pm 14$ & .014 \\
\hline Left liver* & $4 \pm 1$ & $25 \pm 2$ & .000 \\
\hline Spleen & $11 \pm 6$ & $425 \pm 498$ & .416 \\
\hline Gastric wall & $257 \pm 130$ & $175 \pm 25$ & .523 \\
\hline Testis & $67 \pm 20$ & $118 \pm 53$ & .362 \\
\hline Rectus femoris & $137 \pm 50$ & $43 \pm 3$ & .104 \\
\hline Tibialis anterior & $167 \pm 87$ & $50 \pm 18$ & .211 \\
\hline
\end{tabular}

$C P B$, Cardiopulmonary bypass; $R L U$, relative light units. 